\title{
A NARRATÍV ELME TÖRTÉNETI FILOZÓFIÁJA
}

Szécsi Gábor könyvében nem kevesebbre vállalkozik, mint egy alapvető filozófiai tétel felállítására és alátámasztására, mely szerint elménk, saját személyiségünk és maga a valóság számunkra narratívák által és narratívákban jelenik meg. Nem állítja, hogy mindez pusztán narratíva, de azt igen, hogy narratív eseményeken keresztül konstruálódnak, sőt nem is léteznek a narráció nélkül és azon kívül. Könyvében a narrativitás, a beszéd, a kommunikáció egyéni és közösségi identitásképző hatását elemzi a korai történeti időktől a legújabb mediális kommunikáció és kognitív tudomány koráig.

Minden elbeszélés, ami számunkra, emberek számára valóságos, foglalhatnánk össze Szécsi Gábor állítását. A narratív identitás fogalmát Paul Ricœur vezette be (Temps et récit III, Paris, Seuil, 1985, 352-359.) müvének konklúziójában, mint az időbeliség (temporalité) egyik apóriáját. Szécsi Gábor Ricœur tézisét járja körül, alkalmazza a történelmi narrációra és kommunikációra, a történeti identitásképzésre és további témákra. Ennek során a nyelvfilozófia, kommunikációelmélet, kognitív tudomány és modern történelemfilozófia teljes eszköztárát elemzi és használja fel.

Szécsi Gábor eredeti tézist megfogalmazó könyve újdonság a hazai tudományos közegben. A történeti tények, a történelem filozófiai értelmezése Magyarországon évszázados elmaradásban van. Még mindig Hegel feje tetejére állított filozófiájának hatása alatt áll. Jól érzékelhető ez napjaink közéleti, politikai és történettudományi diszkusszióiban is. A huszadik század második felében nálunk egy tizenkilencedik századi elbeszélést erőltettek a múlt értelmezésében, a század végén és a huszonegyedik század első évtizedeiben pedig nem ritkán éppen azok, akik az erőlködésben részt vettek, megpróbáltak a saját maguknak gyártott ideológiai vasabroncsok szorításából kitörni, de nem jutottak tovább egy utánérző, külföldi eszméket megértés nélkül szajkózó, felvizezett és meg nem értett „posztmodern” gondolkodásmódnál, melyet Paul Feyerabend (egyébként általában félreértett) anything goes, „minden lehetséges” kifejezése jellemez legjobban. Kapóra jött ez az elv, mert olyan kontextust teremtett, mely felmentett a történeti felelösség alól.

Szécsi Gábor a történetfilozófia fél évszázados (valójában két évezredes) szerves, tehát a „szocialista” ideológiáktól nem torzított és elmerevített történetfilozófiai fejlődésére épülő mai elméletek alapján tárgyalja a nyelv, a történeti valóság, az individuális identitás összefüggéseit. Felhasználva az új fejleményeket, a világ- és önértés elbeszélő struktúráinak szerkezetét és müködésmódját kutatja, egészen az új médiákig, azok hatásáig az elbeszélésre, az egyén és a társadalom önképére, önalakítására. 
A bevezető fejezet a valóság narrativizálásának elméletét és lehetséges folyamatait mutatja be, a meghatározó szakirodalomra hivatkozva. A társadalmi, kisközösségi, egyéni önmegértés és azonosság vonatkozásában a történetek elbeszélése döntő szerepet játszik, miközben a történetmesélések módozatai jelentősen meghatározzák az elbeszélések hatásmechanizmusát. A kommunikációs eszközök gyors fejlődése valójában a narratívahordozók fejlódése, és ezekkel együtt feltehetően nemcsak az egyén, a társadalom fogja magát másként érteni, nemcsak nekik lesz más identitásuk, hanem beláthatatlan gyakorlati következményei is lesznek az egyéni és közösségi életre, amelyeket a médiumok fejlődésével együtt folyamatosan vizsgálni kell.

A Narrativa, nyelv, cselekvés fejezetben a szerző összekapcsolja a narráció általi identitásképzést a nyelvi és nemnyelvi cselekvéssel, továbbá a kommunikációnak az emberi testtel való szoros együttlétével. Az embodiment vagy megtestesültség paradigma a kommunikáció, nyelv, megértés, tudás, cselekvés, egyáltalán az ember egész tudatos működésének holisztikus felfogása, mely az ember aktivitását egészben, a diszciplínák által nem szétszaggatottan kívánja látni, egészen odáig menve, hogy mindent az emberi test megnyilvánulásának tart. A kötetben Szécsi Gábor páratlan világossággal és kritikai meglátásokkal mutatja be az embodiment paradigma jelentőségét önmagunk és a társadalmi kommunikáció vonatkozásában.

A Narratíva, kommunikáció és népi pszichológia fejezetben a szerző kísérletet tesz arra, hogy a kognitív nyelvészet és a narratív pszichológia elbeszélésfelfogását a népi pszichológiára és az intenció-orientált nyelvfilozófiára alkalmazza. Bemutatja és összekapcsolja e diszciplináris ágazatokat. A népi pszichológia végső soron a hétköznapok kommunikáció- és viselkedési módjaihoz tartozó megértő hozzáállás. A kommunikáció és a cselekvés alapján szándékokat feltételezünk, és ismerve a nyelvi, kulturális, viselkedési, szociológiai hátteret, értelmezni tudjuk a kijelentéseket, majd feltételezni tudjuk, hogy ezekből milyen viselkedések és cselekvések következnek. A népi pszichológia nem kutatja a mélyebb pszichológiai, neurológiai, kulturális, morális összefüggéseket, hanem a kommunikációt és beszédet kísérő szándékokat, hiteket, vágyakat és cselekvéseket valós eseményeknek, fennállásoknak véli, amelyek a létező individuális, közösségi és társadalmi közeget alakítják.

Ebből következik, hogy ha cselekvéssel, intézménnyel találkoznak, a népi pszichológia szerint élők - és valójában mindenki így él a társadalomban - ezek mögött racionalitást, tudatosságot, szándékosságot feltételeznek. Ezek belső és külső narratívákba ágyazottak, amiket a cselekvő maga magának mond, és amiket kifelé közvetít, és amit a kívülállók róla mondanak. E narratívák metszéspontjában értelmezhető egy egyén cselekvése, és tulajdoníthatunk neki bizonyos szándékot vagy szándékokat. Szécsi Gábor kutatásait a klasszikus nyelvfilozófiához kapcsolja, azokhoz a szerzőkhöz, akik a nyelvi összefüggések relációját keresik nem 
nyelvi tényekkel. Ezért fordul John R. Searle és Paul Grice munkáihoz, melyekben a nyelv, a nyelvi jelentés pszichológiai és kognitív tartalmakkal, mentális állapotokkal kapcsolódik össze. Feleleveníti Searle felfogását, mely szerint míg a szavaknak közvetett, addig a gondolatoknak inherens jelentésük van, habár nem elemzi a két jelentés viszonyát, összekapcsolhatóságuk vagy éppen összekapcsolhatatlanságuk vitatható összefüggéseit. Rámutat Jerry Fodor kauzális elméletére, mely szerint a gondolkodásnak saját nem-nyelvi nyelve van, mely oksági kapcsolatban áll a tudaton kívüli tárgyakkal. Ezek a tézisek is áldozatai mindazoknak az ellenvetéseknek, amelyek rámutatnak az egyes tartományok inhomogén és másra redukálhatatlan belső törvényrendszereire. (A nyelv szabályai nem a kogníció szabályai, a kauzális világ szabályai nem a gondolkodási logika szabályai, és sorolni lehetne az inkommenzurabilitásokat, inhomogenitásokat és inkongruenciákat.)

A filozófia egyik fő problémája éppen a kapcsolatiság, a különféle diszciplínákkal és nyelvekkel leírt tartományok egymáshoz illesztése, a számítógépek nyelvén interface-e. Szécsi Gábor így fogalmaz: „A mentalista nyelvelméletek szempontjából tehát kulcskérdés lehet, hogy elfogadható meghatározást tudnak-e kínálni az üzenet tartalmával azonosított, egyéni mentális állapotok és a kommunikáció folyamatában közvetített jelentések kapcsolatáról.” (61.) Ez példa az elöbbi bekezdésben említett problémára; milyen összeillőségben vagy nem-illőségben van az egyéni tudati állapot és a beszédben közvetített jelentéstartalom. A filozófia egész története a különbözők összekapcsolásáról szól, de két és fél ezer év óta nem oldja meg a kotyogásmentes összeillesztést. Ehelyett a fogalomhasználat és a problémakör az idők során eltolódik, igen gyakran az empirikus tudományok hatására, új interface-problematikát nyújtva a filozófusoknak, akik aztán a korábbi összeillesztési kísérleteiket lezáratlanul odahagyva, új területeken kezdik meg vagy inkább folytatják morfológiailag és taxonómiailag a korábbihoz kísértetiesen hasonló munkájukat.

A kommunikáció sikerességének rendkívül sok összetevője van, de a sikerességet megállapíthatjuk, mégpedig a kommunikációhoz kapcsolódó cselekvések hatékonysága alapján. Szécsi Gábor szerint: „Egy kommunikatív aktust akkor tekinthetünk eredményesnek, ha az aktus vevője az adó cselekvéseihez vezető mentális okokat ennek az intencionális tartalomnak a jegyében képes reprodukálni. A nyelvi kommunikáció eredményességének első számú feltétele, hogy a kommunikatív aktus vevője az aktust olyan intencionális eseménynek fogja fel, amelyet a közlő valamely intenciója, vélekedése, vágya stb. idéz elö." (68.) Itt tehát egy lépéssel hátrébb vagyunk, a mentális tartományban. Szécsi Gábor szerint az intencionális tartalom megfelelő reprodukciójában áll a kommunikáció sikeressége. Ez azonban egy metakommunikatív állítás, vagy inkább kommunikáció-metafizikai állítás. Az intenció reprodukálása valóban sikeres kommunikációt jelent, de honnan tudhatjuk, hogy a reprodukálás megfelelö-e, és valóban a kommunikáló tényleges intencióját ragadjuk meg? És tovább mehetünk: tud- 
ja-e a kommunikáló, eredetileg, kommunikációja nélkül, hogy mi az ő saját intenciója? Ha maga is befogadója saját kommunikációjának, mint ahogy minden kommunikáló az is, vajon felismeri benne vagy belőle eredeti szándékát? Nem inkább másként mondaná? Ha újra kommunikálhatná azt, ugyanazt kommunikálná akkor, amikor ugyanazt akarná kifejezni? Szécsi Gábor számos helyen kiemeli, hogy a kommunikáció megértéséhez, ahogy ezt már Donald Davidson is javasolta, beszélgetőpartnerek, emberi közösség és a fizikai világ szükségeltetnek, márpedig ezeket csak folyamatos aktivitásban, cselekvő-kommunikatív megnyilvánulásokban értelmezhetjük. A kommunikatív folyamatok szerkezetének és értelemképzésének a releváns szakirodalom alapján történő kreatív és eredeti feltárása után Szécsi Gábor megfogalmazza tézisét, hogy a megértési folyamatok modellje, melyet a kognitív nyelvészet és pszichológia, az analitikus filozófia és a kommunikációelmélet, valamint a népi pszichológia segítségével kidolgozott, alkalmas a történelmi megértés, a történettudomány értelemképzése és -közvetítése feltárására is.

A Történet és történeti megismerés fejezetben Szécsi Gábor bemutatja a kortárs történetfilozófia metodológiájának fejlődését. A korábbi szubsztantív nagy elbeszéléseket, a történelem metafizikáját, felváltotta a történelem episztemológiája. A Hegel által, de talán már a nagy vallások, legalábbis a Nyugatot formálók által indított hagyománytól eltérően a történelmet nem összefüggő, nagy, egyetlen elbeszélésben, értelmező keretben és értékrendben feltárható folyamatként fogják föl, hanem mint olyat, amelyben egyes emberek, közösségek próbálják megszervezni életüket, és eközben értelmezik környezetüket, múltjukat, egymás és múltbeli emberek cselekedeteit. A nagy elbeszélések korát neopozitivista történelemértelmezési kísérlet követte, azonban a természettudományon edződött tudományfilozófusok, mint Carl Hempel és Karl Popper, a nagy történetlátomás helyett nagy kutatáslogika-víziókat prezentáltak, melyek szintén kerékkötöjévé váltak a valódi történeti megértésnek. Ök is meg akarták menteni a történelem tudományosságát, nem figyelembe véve, hogy ez feltételezi a szigorú kauzalitást, miközben az eseményeknek és a hozzájuk tartozó vagy inkább őket kreáló narrációnak alapeleme a szabadság, mely semmiféle előzetes ideológiai vagy metodológiai keretbe nem fogható. Ahogy a cselekvő szabad, vagyis alternatívák közt dönthet, úgy önmaga mint elbeszélő és cselekvésének kortárs vagy későbbi elbeszélője, további szabadságfokokkal rendelkezik, hogy mit emel ki és mit hanyagol el egy-egy eseményből vagy eseményláncból.

A kiemelések és elhanyagolások ráadásul nem önállóan létező ténynek a puszta szolgai leírásai, de maguk is megalkotják azt az eseményt, amelynek leírói. Ebből az is következik, hogy a narráció révén megkérdőjeleződik vagy viszonylagossá válik az „objektív” történeti tény fogalma, és annyi tény lesz, ahány elbeszélés. Szécsi Gábor vizsgálja a kortárs történetfilozófiai fejleményeket, amelyek felhasználják az ismeretelmélet, a nyelvfilozófia, a tudományfilozófia elemeit. 
A történelmi megismerés narrativista és kontextualista modelljei címü fejezetben visszatér a narrativitás problematikájához, most már a történetírásra fókuszálva, miközben az újhistorizmus történelemelméleti kontribúcióit is kritika alá vonja. Az imént említett többesség, vagyis a narratívák egymásba ágyazódása, egymásra épülése és rétegződése így jelenik meg Szécsi Gábor szövegében, amikor a történeti leírásokról ír: „A cselekvők egyrészt érzékeltetni kívánták a kor népi pszichológiájának megfelelő kódokkal cselekvéseik okát, azaz azt, hogy a konkrét probléma megoldására miért éppen az adott aktus mellett döntöttek a konkrét szituációban választható lehetséges cselekvések közül, másrészt világossá kívánták tenni a hasonló szituációkkal kapcsolatos általános attitüdjeiket is. A cselekvéseket megörökítő történelmi dokumentumok szerzői ugyancsak e kettős narratívaszint jegyében beszélik el a cselekvésekkel és azok vélt okaival kapcsolatos történeteiket. Az adott kor számára valamilyen társadalmi, politikai, ideológiai vagy éppen morális üzenetet megfogalmazó krónikás elsődleges indítéka ugyanis az volt, hogy kortársai számára világossá tegye, miért tartotta fontosnak az általa elbeszélt tettek megörökítését. A dokumentumokat, forrásokat komparatív módon elemző történész e kettős narratív struktúrák metszéspontjában fedezi fel, vagy, hogy az Ankersmit-féle szóhasználattal éljünk, »tapasztalja meg« saját története kiindulópontjait, hogy azután maga is e kettős narratívaszint jegyében tegye megragadhatóvá saját szerzői indítékait. Miután maga is narratívákat rekonstruál a történelmi dokumentumok elemzésekor, azzal a feltevéssel alkotja meg saját történetét, hogy az elbeszélése általa inherensnek vélt történelmi narratívák csomópontjában kap valódi jelentést.” (119-120.) Nem lehetne ennél határozottaban és érthetőbben bemutatni a történetírás összetettségét és egyben a történetírás akár igaz, akár igazságos attribútuma megállapításának lehetetlenségét. Van a cselekvő, aki értelmezi cselekvését, van a korabeli krónikás, aki maga tovább értelmez, tágabb történeti, vallási, kulturális, ideológiai és sok egyéb kontextusba helyezi a cselekedetet, majd érkezik a mai történetíró, aki maga is feltételezésekkel, iskolázottsággal, módszertani felkészültséggel és vele járó elfogultságokkal rendelkezik, hatalmi viszonyokba ágyazottan saját életstratégiája és sok más rabjaként, amelyek befolyásolják a maga narratíváját. A történelem narratívák egymásra rétegeződése, egymásba ágyazódása lesz, miközben a történeti tény és tett fogalma egyre inkább értelmezhetetlenné, megközelíthetetlenné válik. Szeretném megjegyezni, hogy Szécsi Gábor nem megy el e relativizmushoz közelítő megállapításig, mindvégig kitart amellett, hogy a rendkívül összetett történeti ténykonstrukció, kezdve magától $a z$ aktustól egészen a mai értelmezésig, valódi tény- és eseményfeltáró lehet, ahol a történeti valóság szövete jelentéssel, jelentésalkotással és jelentéskereséssel teli kommunikáció.

A Mediatizáció és narrativa fejezetben a szerző az új médiumok hatását vizsgálja a közösségek és benne az egyének életére. Az emberi csoportosulásokat, közösségeket a közös világlátás, cselekvés, élmények, nyelv, kultúra és múlt 
köti össze. A hagyományos közösségekben az emberek közvetlenül ismerték egymást, családjaikat, közeli felmenőiket, osztoztak egymás sorsában, közösek voltak az örömök és a bánatok. A közösségek összetartó ereje a kommunikáció, a klasszikus korban mindenki beszélt mindenkivel, a családon belül, a település utcáján, a munka, a szolgáltatás közben. A mindenkori technikai fejlettséggel összefüggő kommunikációs mód teljes mértékben meghatározza a közösségek fennállásának és müködésének jellegét. Az iparosodással, nagyvárosok kialakulásával, a technológiai fejlődéssel a kommunikáció és a közösségek is megváltoztak. A társadalom tömegesedésével szükségessé vált a kis- és nagyközösség fogalmi szétválasztása, melynek egyik változata Ferdinand Tönnies közösség-társadalom (Gemeinschaft - Gesellschaft) ikerfogalma. A modern korban létrejött nagyvárosok, nemzetállamok olyan társadalmakat hoztak létre, melyek túlmutattak a kisközösségeken, és amelyek új identitásképző erővel, megváltozott kommunikációs módokkal új hatalmi viszonyképzésekkel léptek föl. A könyvnyomtatás után megjelent a távíró, a telefon, a rádió, már nemcsak szemtől szembe vagy könyveken keresztül lehetett egymással érintkezésbe lépni, de távoli helyeken élők is kapcsolatba kerülhettek a közlekedési időtényező kizárásával. Az ipari termelés, közlekedés és kommunikáció felgyorsulása magával hozta a technológia, a matematika olyan fejlődését,amely elvezetett a számítógépekhez és az új médiákhoz. A mobiltelefon, az internet és járulékaik megszüntették a klasszikus kommunikációt, annak terét és idejét. Nincs többé térbeli és időbeli akadály az eszmecsere előtt. Ennek ma még beláthatatlan következményei alakulnak, és Szécsi Gábor az elmúlt évtizedek vonatkozó szakirodalmát feltárva és értelmezve mutat rá a közösségi, mindennapi, társadalmi, önértelmező és önszervező individuális élet robbanásszerủ átalakulásának összefüggéseire. Az új társalgásmód mindig új közösségi formákat és új közösségeket hozott létre, ezért Szécsi Gábor magyar nyelven úttörő írása különös figyelmet érdemel azoktól, akik napjaink társadalmi szerkezetátalakulásait valamelyest megérteni vagy nyomon követni szeretnék.

Az identitásformáló narrativák mediatizációja címü fejezetben azt vizsgálja a szerző, hogy az új médiák milyen hatással vannak azokra az elbeszélésekre, tartalmukra, szerkezetükre, amelyek közösségeket és egyéneket hoznak létre. Az új egyén a hálózati individuum, ahogy Szécsi Gábor nevezi, és vizsgálja ennek az új, állandóan változó, a fluid hálózatok áramaival és áramköreivel fenntartott képződménynek kommunikációs konstitutív elemeit, életmódját, társadalmi viszonyrendszerét, közösségalkotási képességét.

Szécsi Gábor a történelem, a kommunikáció, a narráció összefüggésének elméleti tablóját és elemzését adja. Hatalmas technológiai és informatikai, kommunikációs robbanás kellős közepén vagyunk, folyamatokban, melyeknek számos elemét látni és érteni véljük, de nem ritkán tanácstalanul állunk a változások iránya vonatkozásában. A mü alapvető, magyar nyelven ismeretlen területeket 
és szempontokat von hatókörébe, és gondolatmenetei, meglátásai a nemzetközi diszkusszióhoz is hozzájárulhatnak, ha angol nyelven is hozzáférhetők lesznek.

Későbbi munkák során érdekfeszítő lehetne megvizsgálni az etika, a hatalom és az anyagi képesség, a pénz hatását a kommunikációs folyamatokra, azok nyíltságára. Azt például, hogy a pénz birtoklása milyen mértékben ad hatalmat a kommunikáció befolyásolására, a kommunikációs eszközök kézben tartására, illetve magának a pénz, a még több pénz és még több hatalom megszerzésének. Az emberiség történetének állandó velejárója a gyakran nem nyíltan feltett kérdés, „Hol a pénz?”, és hogy tudja az ember a lehetö legtöbbet a lehetö legkisebb fáradsággal megszerezni. Egyetlen korszak, az internet kora sem hozott változást abban, hogy a pénz továbbra is el van rejtve, és úgy tünik, viszonylagosan ugyanolyan kevesen tudják ma, hogy hol a pénz és hogy lehet hozzájutni, mint tudták a korábbi médiák esetében. A „hol a pénz?” kérdésének szinonimája a „hol a tudás?” kérdése is. A „hol a pénz?” kérdésre a választ tudók nem vesznek részt a nyílt kommunikációban, továbbra is a háttérben maradnak. Sajátos lenne megvizsgálni, a papíralapú, fémalapú, múanyagalapú és informatikaalapú biztonságtechnikák napjainkbéli robbanásszerủ átalakulását. Az ezt feltaláló, müködtető és megvásárló cégek internetes honlapjait hiába keressük, vagy ha igen, akkor éppen fö tevékenységükről tudhatunk meg a legkevesebbet. A gazdaság, a pénzügyek és az ezekhez kapcsolódó tudás átalakulása az új médiákkal - a Szécsi Gábor által végzett kutatások egy lehetséges további útja lehetne.

A szerző szaktudományos tájékozottsága és elemző készsége páratlan, a kötet olvasása valamennyi diszciplína mủvelőjének ajánlható.

(Szécsi Gábor: A történetekbe zárt elme. Adalékok a narrativitás filozófiájához, Budapest: Akadémiai Kiadó, 2020. 187 o.

Boros János

egyetemi tanár, Pécsi Tudományegyetem 